Las Torres de Lucca. Revista internacional de filosofía política

ISSN-e: 2255-3827

\title{
Montesquieu o Spinoza. La política y la historia en Louis Althusser ${ }^{1}$
}

Esteban Domínguez ${ }^{2}$

Recibido: 8-4-2021 / Aceptado: 1-11-2021 / Publicado: 30-01-2022

Resumen. En este artículo propongo una lectura de los primeros capítulos de Montesquieu. La politique et l'histoire (1959) de Louis Althusser con el fin de señalar el modo en el que las primeras menciones a Spinoza en la obra de Althusser se producen junto a Montesquieu y reflexionar sobre el sentido crítico de esas menciones. Con un estudio como este quisiera, primero y en general, señalar la importancia no siempre del todo reconocida que tuvo Montesquieu en el desarrollo teórico de Althusser. Segundo, analizar el significado de las alusiones críticas a Spinoza presente en este escrito. Y, tercero, indicar los trazos que configurarían las condiciones de posibilidad de la integración del spinozismo al pensamiento de Althusser.

Palabras clave: Althusser; Montesquieu; Spinoza; ley-relación; dialéctica de la historia.

\section{[en] Montesquieu or Spinoza. Politics and History in Louis Althusser}

Abstract. In this article, I propose a comprehensive reading of the first chapters of Louis Althusser's Montesquieu. La politique et l'histoire (1959), with the aim of pointing out the way in which the first mentions of Spinoza in Althusser's work appear next to Montesquieu, and to think about the critical sense of those mentions. I would like, firstly and in general terms, to emphasize on the importance, not always recognized, that Montesquieu had on Althusser's theoretical development. Secondly, to analyze the meaning of the critical references to Spinoza that are present in this book, and to indicate the lines that would configure the conditions of possibility for the integration of Spinozism into Althusser's thought.

Keywords: Althusser; Montesquieu; Spinoza; law as a relation; dialectic of history.

Cómo citar: Domínguez, E. (2022). Montesquieu o Spinoza. La política y la historia en Louis Althusser. Las Torres de Lucca. Revista internacional de filosofia politica, 11(1), pp. 153-167. https://dx.doi.org/10.5209/1tdl.77225

La presencia de Spinoza en la obra de Louis Althusser ha sido frecuentemente señalada y profundamente estudiada (Althusser, 2008c; Montag, 2013; Peden, 2014; Sánchez Estop, 2020). Sin embargo, una investigación sobre los orígenes de su spinozismo no ha sido más que esbozada. En este trabajo quisiera recorrer una porción de esta historia que se dibuja en los comienzos de su spinozismo reflexionando sobre la presencia del holandés en el primer libro publicado por Althusser: Montesquieu. La politique et l'histoire (1974). ${ }^{3}$

Hacer de este libro de Althusser el punctum ${ }^{4}$ de un estudio sobre los orígenes de su spinozismo resulta pertinente puesto que luego de la publicación de MPH se produce un recomienzo por medio de un abandono, si no de los problemas esbozados en su primer libro, sí del nombre propio de Charles de Secondat como antecedente directo de Marx. De modo que a la par de la reducción paulatina de las referencias a la filosofía del siglo de las luces y de Montesquieu en particular, comienzan a emerger las primeras referencias a Spinoza. Desde ese momento, y en adelante, Montesquieu aparecerá en la conciencia filosófica de Althusser como una adaraja en la pared a la espera de una unión con otra. Más específicamente, Montesquieu aparecerá como

\footnotetext{
Este artículo es el resultado parcial de una investigación realizada durante una residencia en el Institut Mémoires de l'Édition Contemporaine (IMEC) en el año 2019 en el marco del Programme Odyssée - Association des Centres culturels de rencontre (ACCR), con el apoyo del Ministère de la culture et de la communication de Francia.

2 Facultad de Ciencia Política y Relaciones Internacionales, Universidad Nacional de Rosario, Consejo Nacional de Investigaciones Científicas y Técnicas, Argentina.

Correo electrónico: esteban.dominguez@live.com.ar

ORCID: https://orcid.org/0000-0001-7864-2140

En adelante, Montesquieu. La politique et l'histoire será resumido por sus iniciales: MPH.

4 Retomando la noción de Roland Barthes (1990) para designar aquello en una fotografía que no se busca sino que "sale de la escena como una flecha y viene a punzarme" (p. 64). Se trata de un "pinchazo, agujerito, pequeña mancha, pequeño corte, y también casualidad. El punctum de una foto es ese azar que en ella me despunta (pero que también me lastima, me punza)” (p. 65). El punctum es, también, "una especie de sutil más-allá-delcampo, como si la imagen lanzase el deseo más allá de lo que ella misma muestra" (p. 109).
}

Las Torres de Lucca. 11 (1), 2022: 153-167 
"ese último espejo" en el que Althusser se contempló, "antes de rechazar esa imagen prestada, para sumir su verdadero rostro" (Althusser, 1983b, p. 38). ${ }^{5}$ De ahí que sea pertinente estudiar ese reflejo esperando cierta iluminación en la comprensión que actualmente se tiene del spinozismo de Althusser.

Entre los libros publicados en vida por Althusser, MPH se presenta como una excepción avant la lettre; la de una regla que aún no se había hecho visible. Primero, porque no trata sobre Marx ni, en principio, el marxismo. Excepción también porque la estructura del texto dista de la función recopilatoria de una dispersión previa tan característica de sus otros libros desde Pour Marx (1983a) y Lire le capital (2004a, 2004b) hasta Positions (1982). En el límite, se podría decir que MPH no solo fue el primer libro, sino que también fue su único libro con un autor que firma sin fecha, que propone capítulos en los que se dibuja un orden de exposición: una introducción, seis capítulos, una conclusión, la bibliografía utilizada. ¿Qué hubiera sido de Althusser si hubiera escrito otros libros como ese? ¿Por qué escribir sobre Montesquieu, esa figura tan ilustre tallada en mármol y no sobre esos rostros más salvajes que nos atraen, los de Marx, Spinoza o Maquiavelo? Frente a MPH uno se enfrenta a un libro singular, de un autor singular. El primer libro de Althusser antes de ser Althusser, es decir, el último.

Pero no solo es su primer libro, sino que también es el primer escrito del autor en el que la figura de Spinoza emerge de manera explícita y tiene una importancia, aunque limitada, en el desarrollo de sus tesis. Se trata de referencias frecuentes a lo largo del primer capítulo ligadas en general a otros filósofos políticos, inscribiéndolo en la constelación teórica de los filósofos del derecho natural. Además, las referencias suelen ser críticas, señalando el carácter de precursor de Spinoza frente a Montesquieu por medio de las limitaciones del primero frente al segundo. De modo que, si Spinoza está allí no es para conocer su vida y su obra sino simplemente para ver mejor otro rostro. La oposición entre ambos es realizada mediante la disposición del escenario que posibilite un primer acercamiento desde el cual pueda resultar, luego, cierto efecto de distanciamiento.

En este artículo propongo una lectura de los primeros capítulos de MPH, con el fin de señalar el modo en el que las primeras menciones a Spinoza en la obra de Althusser se producen junto a Montesquieu y reflexionar sobre el sentido crítico de esas menciones. Con un estudio como este quisiera, primero y en general, señalar la importancia no siempre del todo reconocida que tuvo Montesquieu en el desarrollo teórico de Althusser, expresada en su rechazo a las filosofías del origen, en el descubrimiento de las implicancias filosóficas de una nueva concepción de la noción de ley y en la indagación sobre los procesos de causalidad histórica atravesados por múltiples determinaciones. Segundo, y más en particular, analizar el significado de la alusión crítica a Spinoza presente en este escrito e indicar los trazos que configurarían las condiciones de posibilidad de la integración del spinozismo al pensamiento de Althusser.

En un primer momento, señalaré la relación establecida entre Spinoza y Montesquieu en el capítulo 1 de MPH, según la cual existe una proximidad entre ambos que posibilita la comprensión de la novedad del señor de la Brède frente a sus predecesores. De este modo, se verá que las primeras menciones textuales a Spinoza se producen bajo la modalidad de la alusión crítica. En un segundo momento, analizando los dos problemas abordados en los capítulos 2 (la ley-relación) y 3 (la dialéctica de la historia) de MPH, mostraré el modo en el que se configuran las condiciones de posibilidad para el inminente ingreso de Althusser en el terreno de la filosofía marxista, pero también, de cierto spinozismo.

\section{Montesquieu crítico de Spinoza}

Es en el primer capítulo de MPH donde la figura de Spinoza emerge por primera vez en los escritos de Althusser. ${ }^{6}$ Todo el capítulo 1, "Una revolución en el método", está construido como una puesta en escena en la que los personajes son dispuestos de modo tal que uno de ellos sea identificado por su novedad. No se trata de un contraste entre pensadores opuestos sino de mostrar en su proximidad la singularidad de uno frente a los otros. Se trata de señalar la novedad de Montesquieu frente a su pasado teórico respecto a dos cuestiones capitales: la primera, sobre el carácter de la ciencia y su objeto; la segunda, sobre el fundamento de lo social y el sentido de la historia.

El capítulo comienza con una verdad admitida bajo el influjo de Comte y Durkheim: considerar a Montesquieu como el fundador de la ciencia política. ${ }^{7}$ Para Althusser, por su parte, no se trata de repetir esa verdad sino de demostrarla: indicar diferencialmente la originalidad de Montesquieu frente a empresas, en

En Les manifestes philosophiques de Feuerbach Althusser afirmaba: "Feuerbach mismo, este último testigo de la 'conciencia filosófica' del joven Marx, este último espejo en el que Marx se contempló, antes de rechazar esa imagen prestada, para asumir su verdadero rostro" (1983b, p. 38).

6 Antes de MPH, las referencias de Althusser a Spinoza son verdaderamente escasas. El holandés solo es mencionado de manera significativa en la Mémoire redactada por Althusser para la finalización de sus estudios en la École Normale Supérieur: Du contenu dans la pensée de G. W. F. Hegel (Althusser, 1994). Sin embargo, un estudio a la letra de ese escrito permite reconocer que todas las referencias de Althusser al autor de la Ética allí realizadas se inscriben en la propia lectura hegeliana del Spinoza.

Según Durkheim (2001) fue Montesquieu quien “estableció los principios de la nueva ciencia," quien "dio conciencia de su objeto, de su naturaleza y de su método," y nadie antes que él "había avanzado tan lejos por el camino que condujo a sus sucesores a la verdadera ciencia social; nadie había discernido tan claramente las condiciones necesarias para el establecimiento de esta ciencia” (pp. 19-20). 
principio, análogas. La obra comienza, entonces, con un ensayo de delimitación de Montesquieu frente al pensamiento moderno que creyó hacer una ciencia de lo político. Entre Bodin, Hobbes y Grocio emerge por primera vez el nombre de Spinoza para ilustrar la primera tesis, sobre el carácter de la ciencia y su objeto como constitutiva de la originalidad de Montesquieu. En el marco del nacimiento y desarrollo de la física matemática en el siglo XVI se ve nacer, dice Althusser (1974), una "física moral o política" (p. 12) que antecede a la oposición que sobrevendrá posteriormente entre las ciencias de la naturaleza y las ciencias del hombre y que pretendió hacer una ciencia de lo político: "los moralistas, los filósofos del derecho, los políticos, y el mismo Spinoza, no dudan un instante de que se pueden tratar las relaciones humanas como relaciones físicas" Althusser nos invita a leer la introducción al Tratado político en la que Spinoza denuncia a los "filósofos puros que arrojan sobre [jettent sur] la política lo imaginario de sus conceptos o de su ideal" y propone, en cambio, "la ciencia real de la historia, en lugar de sus sueños" (1974, pp. 12-13). ${ }^{8}$

Pero si esto es así, ¿cómo explicar la novedad de Montesquieu? El señor de la Brède, aunque aparente continuar un mismo camino, "no va al mismo objeto.... Él se proponía como objeto la historia entera de todos los hombres que han vivido" (1974, p. 14). Lo cual solo es comprensible a partir de una doble revolución de los siglos XV y XVI: "una revolución en su espacio", puesto que se trata del tiempo de las grandes exploraciones que abren Europa al exotismo de oriente a occidente; "una revolución en su estructura", que sacude los cimientos de las convicciones europeas (guerras civiles, la Reforma, las transformaciones del Estado, el auge plebeyo) y que hace de la curiosidad ante el nuevo mundo algo más que rarezas e historias por compilar: el nuevo mundo "se convierte en el espejo de las inquietudes presentes y en el eco fantástico de este mundo en crisis" Es de ese reflejo que Montesquieu hace su objeto: reflexionar sobre "todos los usos y todas las leyes del mundo" (1974, p. 15).

Esto mismo señala la insuficiencia del resto de los filósofos frente a la revolución de método impulsada por Montesquieu. Sorprende, sin embargo, encontrar aquí una crítica directa a Spinoza, la cual para cualquier spinozismo bien entendido sería evidentemente infundada. Según Althusser, figuras como las de Hobbes y Spinoza si bien proyectaban una ciencia, no la practicaron puesto que, contra la posibilidad de hacer una teoría de la historia real, terminaron por formular una teoría de la esencia de la sociedad:

los teóricos del estilo de Hobbes, Spinoza y Grotius, proponen la idea de una ciencia, pero no la hacen. Reflexionan, no sobre la totalidad de los hechos concretos, sino sobre algunos (como Spinoza sobre el estado judío y su ideología en el Tratado teológico político), o bien sobre la sociedad en general, como Hobbes en el De cive y en el Leviatán, o como el propio Spinoza en el Tratado Político. No hacen una teoría de la historia real, hacen una teoría de la esencia de la sociedad.... Se limitan a analizar la esencia de la sociedad y a dar un modelo ideal y abstracto (1974, p. 15).

La distancia que separa a Spinoza de Montesquieu, afirma Althusser, es "la misma distancia que separa la física especulativa de un Descartes de la física experimental de Newton": mientras una alcanza de manera directa, "en esencias o naturalezas simples, la verdad a priori de todos los hechos físicos posibles", la otra, "parte de los hechos, observando sus variaciones para extraer las leyes" (1974, p. 15). Esta revolución en el objeto va unida así a una revolución en el método. Es cierto, Montesquieu no fue el primero en pretender alcanzar una física social, pero sí fue el primero en darle el impulso de la física nueva:

se ve, pues, a la vez, lo que une a Montesquieu con los teóricos que lo precedieron, y lo que lo distingue de ellos. Tienen en común un mismo proyecto: edificar la ciencia política. Pero aquél no tiene el mismo objeto, pues se propone hacer la ciencia, no de la sociedad en general, sino de todas las sociedades concretas de la historia. Y, por ello, no tiene el mismo método, pues no quiere captar esencias, sino descubrir leyes. Esta unidad en el proyecto y esta diferencia en el objeto y en el método hacen de Montesquieu el hombre que ha dado a las exigencias científicas de sus predecesores la forma más rigurosa, y, a la vez, el adversario más decidido de la abstracción de aquéllos (1974, p. 16).

La posibilidad de afirmar que la política y la historia pudieran ser objeto de una ciencia implica un doble combate. Contra el escepticismo, primero, que pretende tomar a la historia, al decir de Macbeth, como el cuento de un idiota lleno de ruido y de furia, mostrando que en el mar de causas los seres humanos son movidos por algo más que por sus fantasías, por algo que "si no es siempre razonable, es por lo menos siempre racional". Contra toda tentación teológica de tonalidad pascaliana, segundo, que hace del desconcierto escéptico una coartada de cierta razón divina oculta, mostrando que "la necesidad que gobierna la historia debe dejar de tomar prestada su razón de cualquier orden trascendente a la historia" (1974, p. 17).

Es en esas mismas páginas donde vuelve a ser mencionado Spinoza, esta vez del lado de Montesquieu, al recordar la reacción de Bossuet contra Richard Simon y contra Spinoza por haber propuesto una historia

Es sabido que el Tractatus politicus de Spinoza (1677/2010) comienza con una oposición entre dos visiones: la de "los filósofos" que conciben los hombres (y su política) no como son sino como quisieran que fueran, y la de "los políticos" que tomaron la experiencia como maestra (pp. 81-83). 
del pueblo judío y de las sagradas escrituras. Para comprender lo que se juega en esta referencia es necesario realizar un breve rodeo. Luego de la publicación De l'esprit des lois, Montesquieu recibió una serie de ataques provenientes de los censores jansenistas en las Nouvelles ecclésiastiques, tres años después su obra fue introducida en el Index. La acusación tenía diversas implicancias pero todas se resumen en una cuestión en las que los jansenistas reúnen sin demasiada precisión deísmo y spinozismo: Montesquieu es señalado como un partidario, a la vez, de una religión natural, es decir, de una religión despojada de los elementos imaginativos, y de spinozismo, es decir, en aquel contexto, de ateísmo. De l'esprit des lois tuvo así su propia querella del spinozismo, y la acusación fue tan fuerte, que Montesquieu dedicará buena parte de su Défense a demostrar que "il n'y a point de spinosisme dans l'Esprit des lois [No hay spinozismo en el Espíritu de las leyes]" $\left(1750 / 1979\right.$, p. 423). ${ }^{9}$

Pero la respuesta a estas acusaciones no disipa el dilema en el que fue colocado por sus críticos. Por un lado, en su respuesta refuerza la posición que había causado recelo: reducir la explicación de lo humano a causas propiamente humanas. Para Montesquieu introducir la teología en la historia significa confundir los órdenes: si bien los objetos de ciencia pueden tener un sentido religioso, éstos "dependen también y, primeramente, de un orden autónomo que tiene sus propios principios" (Althusser, 1974, p. 19). Si la religión no puede servir como ciencia de la historia, también la moral se revela insuficiente. Aquí Montesquieu, reconoce Althusser, no está lejos de Hobbes o Spinoza:

[Montesquieu] responde a los moralistas que solo quiere hablar humanamente del orden humano de las cosas, y políticamente del orden político. Él defiende su convicción más profunda: que una ciencia de la política no puede fundarse más que sobre su propio objeto, sobre la autonomía radical de lo político como tal (1974, p. 20).

Por otro lado, Montesquieu intenta conciliar las posiciones: reconocer que se trata de órdenes distintos es la condición misma para salvaguardar esos mismos órdenes. Un spinozista jamás lo reconocería, parece querer decir Montesquieu. Un spinozista no cultiva el arte de la distinción tan sutil como el que irá unido al nombre del señor de la Brède. Con ironía, y quizás sobreactuando, Montesquieu se desmarca, remitiéndose a todas las confesiones de fe con las que ya había revestido De l'esprit des lois, I, I: no podría ser spinozista él que distinguió el mundo material de las inteligencias espirituales; él que rechazó la posibilidad que de una fatalidad ciega pudieran alguna vez haber surgido seres inteligentes; él que sostuvo que Dios se relaciona con el Universo en cuanto creador y conservador; él que afirma que está impreso en nuestras mentes como una ley natural "l'idée d'un créateur [qui] nous porte vers lui [La idea de un creador [que] nos lleva hacia él]"; no podría ser spinozista, en fin, "qui a demontré contre Hobbes et Spinoza, que les rapports de justice et d'équité étaient antérieurs à toutes les lois positives [Quien ha demostrado contra Hobbes y Spinoza, que las relaciones de justicia y de equidad eran anteriores a todas las leyes positivas]" (Montesquieu, 1750/1979, p. 420). Montesquieu concluía lamentándose de que sus críticos vieran en él una amenaza cuando hubieran debido reconocerlo del mismo lado frente a un enemigo común, el spinozismo:

il en résulte toujours que l'auteur a attaqué les erreurs de Hobbes, et les conséquences de celles de Spinosa ; et qu'il lui est arrivé qu'on l'a si peu entendu, que l'on a pris, pour des opinions de Spinosa, les objections qu'il fait contre le spinosisme. Avant d'entrer en dispute, il faudrait commencer par se mettre au fait de l'état de la question; et savoir du moins si celui qu'on attaque est ami ou ennemi [De ello resulta que el autor atacó siempre los errores de Hobbes, y las consecuencias de los errores de Spinoza; y le ocurrió que se lo escuchó tan poco, que se ha tomado por opiniones de Spinoza las objeciones que hizo contra el spinozismo. Antes de entrar en disputa, sería necesario comenzar por informarse acerca del estado de la cuestión; y saber al menos si al que se ataca es amigo o enemigo] (1750/1979, p. 421).

Pero, puesto que existe una ambigüedad en la posición, el problema no se resuelve con confesiones de fe, intentos de conciliación o la puesta en juego de una política de la amistad. Althusser lo reconoce: no basta con distinguir los órdenes puesto que ellos se encabalgan unos sobre otros. Así, si seguimos el razonamiento de Montesquieu debemos concluir que la propia religión y moral están expuestas al orden de lo político. Montesquieu malvive este descubrimiento porque si bien expone los argumentos de una teoría sociológica de las creencias religiosas y morales no termina de aceptar la lección que de estos argumentos se desprende: la subsunción entre los diversos órdenes. "Así es como Montesquieu retrocede, no atreviéndose a saltar"; lo cual explica, cree Althusser, "lo endeble de su defensa" frente a la acusación de ateísmo (1974, p. 21).

"Il dit que le système de la religion naturelle rentre dans celui de Spinoza: et moi, je lui dis qu'ils sont contradictoires, et que c'est par la religion naturelle qu'on détruit le système de Spinoza. Je lui dis que confondre la religion naturelle avec l'athéisme, c'est confondre la preuve avec la chose qu'on veut prouver, et l'objection contre l'erreur avec l'erreur même; que c'est ôter les armes puissantes que l'on a contre cette erreur [Dice que el sistema de la religión natural entra en el de Spinoza: y yo le digo que confundir la religión natural con el ateísmo es confundir la prueba con la cosa que se quiere probar, y la objeción contra el error con el error mismo; que es privarse de las potentes armas que se tienen contra este error]" (1750/1979, p. 434). Sobre la preocupación de Montesquieu por las polémicas religiosas que su obra pudiera haber ocasionado cf. Vernière (1954, pp. 447-465), Spector (2016, pp. 28-30, 52-53, 223-224), Israel (2017, pp. 29-31). 
Como puede verse, para Althusser Montesquieu está más cerca de figuras como Hobbes y Spinoza que lo que él hubiera podido admitir: los "dos principios previos a toda ciencia política" (no juzgar la historia con criterios religiosos o morales; situar a la religión entre los hechos históricos y someterlas a la misma ciencia) "no distinguen radicalmente a Montesquieu de sus predecesores" como Hobbes y Spinoza que usaban el mismo lenguaje y fueron acusados de ateos (1974, pp. 22-23). Unos seis años después, Althusser (2004b) reconocerá retrospectivamente el efecto que la filosofía de Spinoza tuvo en Montesquieu, señalamiento, por lo demás, ausente hacia 1959:

La filosofía de Spinoza introdujo una revolución teórica sin precedentes en la historia de la filosofía..., la mayor revolución filosófica de todos los tiempos, hasta el grado que podemos considerar a Spinoza, desde el punto de vista filosófico, como el único antepasado de Marx. Sin embargo, esta revolución radical fue objeto de un prodigioso rechazo histórico.... La insistencia con la que los siglos XVII y XVIII oficiales se ensañaron contra la memoria de Spinoza, la distancia que todo autor debía tomar ineludiblemente, con respecto a Spinoza, para tener derecho a escribir (cf. Montesquieu), testimonian no solamente la repulsión sino también la extraordinaria atracción de su pensamiento. (2004b, p. 113).

De este rodeo es posible extraer una concusión general. Si Spinoza no ocupa un lugar preeminente de manera explícita en De l'esprit des lois, sí ocupó un lugar fundamental como espectro amenazante que era necesario conjurar, tal como se expresa en la Défense. El asunto era tan importante que Althusser en su comentario no puede ignorarlo, aunque pasa de página demasiado rápido. ¿Por qué una vez reconocida la proximidad entre Montesquieu y Spinoza Althusser sigue su camino? ¿Por qué a pesar de los límites de Montesquieu que lo muestran como una figura menos radical que Spinoza, Althusser se empeña en mostrar el carácter revolucionario del pensamiento del señor de la Brède frente a sus predecesores? A partir de ese momento, luego de señalar la proximidad entre Montesquieu y Spinoza, luego de señalar las concesiones religiosas de Montesquieu, Althusser se empeña en descubrir la singularidad del autor De l'esprit des lois. Estamos en la página 23 del libro y aquí comienza la criticidad del discurso, ni de los jansenistas, ni de Montesquieu, sino del propio Althusser contra Spinoza.

\section{Althusser contra Spinoza}

Mediante la búsqueda de la diferencia específica de Montesquieu respecto a Hobbes y Spinoza se llega a la segunda cuestión que, según Althusser, ilustra la novedad De l'esprit des lois: la cuestión del fundamento de lo social y al sentido de la historia. Luego de reconocer que los tres habrían coincidido en no juzgar la historia con criterios religiosos y en situar tanto a la religión como a la moral entre los hechos históricos, sometiéndolas al conocimiento racional, Althusser afirma que la singularidad de Montesquieu consiste "en que defiende una opinión contraria a la de estos teóricos cuyo heredero es, y en que se opone en un punto decisivo a las teorías del derecho natural" (1974, p. 23).

Para explicarse, Althusser se ve obligado a realizar un rodeo por las filosofías modernas del derecho natural propia de los teóricos políticos de los siglos XVII y XVIII. Aquí vuelve a emerger Spinoza inscribiéndolo por completo en esa constelación teórica entre Hobbes, Locke y Rousseau. Estas filosofías se reúnen en torno a la pregunta por el origen de la sociedad, y a la respuesta por medio del dispositivo teórico del pacto. Para dar con "el origen radical de la sociedad" las filosofías del derecho natural creen que es preciso tomar a los hombres en el estado de naturaleza, "un estado que sea la nada social" (1974, p. 24). Este estado "ignorante de toda sociedad", continúa Althusser, "contiene y figura de antemano el ideal de una sociedad que hay que crear" De este modo, "el fin de la historia está inscrito en el origen" condensado en el estado de naturaleza (1974, p. 26).

Por su parte, la idea del contrato es la que asegura el paso de la nada social a la sociedad existente, y detrás de su problemática se esconde la afirmación de que la sociedad no es el efecto ni de una institución divina ni de una producción natural; se rechaza así la antigua idea de los cimientos del orden social y se impone la tarea de pensar una nueva. En estas teorías se perfila el rostro de sus adversarios: "las convicciones propias del orden feudal, la creencia en la desigualdad 'natural' de los hombres, en la necesidad de los órdenes y los estados," puesto que en general "la doctrina de la sociabilidad natural o del instinto de sociabilidad designa una teoría de inspiración feudal" (1974, p. 26). En cambio, las doctrinas del contrato social al expresar una protesta contra el viejo orden dejan ver una "teoría de inspiración burguesa". Allí "se adivina un orden social y político que se derrumba, y unos hombres que fundan sobre ingeniosos principios el orden nuevo que quieren defender o edificar" (1974, p. 27). Pero, por otro lado, es su mismo "carácter polémico y reivindicativo" el que explica "su abstracción y su idealismo". Si los teóricos del derecho natural no se propusieron el objeto de Montesquieu (comprender la infinita diversidad de las instituciones humanas) es por un motivo que hay que buscar, más acá de toda pretensión científica, en la política: 
su propósito no era explicar las instituciones de todos los pueblos del mundo, sino luchar contra un orden establecido o justificar un orden naciente o a punto de nacer. No querían comprender todos los hechos, sino fundar, es decir, proponer y justificar, un orden nuev (Althusser, 1974, p. 27).

Por este motivo, no tendría sentido buscar "una verdadera historia" en Hobbes o Spinoza ya que ellos "se interesaban solo por el derecho, es decir, por lo que debe ser" Estos teóricos permanecieron así, sostiene Althusser, en una postura polémica e ideológica, presentando el partido que habían tomado en la historia efectiva como la razón misma de la historia de modo que sus principios eran los "valores comprometidos en las luchas de su época" (p. 28). ${ }^{10}$ Unos años después, en sintonía con esto, Althusser (2008a) afirmará que "en los teóricos políticos del derecho natural, la estructura del estado de naturaleza expresa sus pensamientos fundamentales, o incluso sus segundas intenciones" (p. 44). En ellos, el orden civil aparece como dibujado en líneas de puntos en el estado de naturaleza, el descubrimiento del orden político no es más que "el descubrimiento de una ley preexistente, que expresa la esencia de la naturaleza humana", el conocimiento del orden político "no es más que un reconocimiento" (2008a, p. 40) Al plantear el problema del origen, los filósofos del derecho natural son políticamente revolucionarios, puesto que plantear la pregunta por el origen de una institución significa sacudirla. Pero por otro lado son filosóficamente idealistas, puesto que hacen de ese origen una reserva ideal, depositando el ideal político en el origen postulado.

Aquí se percibe, cree Althusser, la distancia que separa al señor de la Brède de esa perspectiva: toda su oposición a los filósofos del derecho natural está basada en un cuestionamiento a su reducción al origen. Frente a ellos, Montesquieu rechaza el esquema del origen de una sociedad describiéndolo como absurdo en su planteamiento y afirma que la sociedad se precede a sí misma:

siempre que he oído hablar de derecho público, he visto que comenzaban investigando atentamente cuál era el origen de las sociedades, cosa que me parece ridícula. Si no se asociaran los hombres, si se desviaran y huyeran unos de otros, entonces sí que sería necesario averiguar la causa, indagando por qué vivían apartados, pero todos nacen conexos unos con otros: un hijo nace al lado de su padre y se queda con él: ahí está la sociedad y la causa de la sociedad. (Montesquieu, 1721/2000, p. 181).

Es cierto, reconoce Alhusser, que en De l'esprit des lois, I, II son formuladas cuatro leyes naturales, pero el contrato está ausente y en su lugar emerge la cuarta ley natural: cierto instinto de sociabilidad, "el deseo de vivir en sociedad" (Montesquieu, 1748/1984, p. 34). En esta posición teórica encontramos, según Althusser, la primera indicación sobre la razón profunda del rechazo a las teorías del derecho natural por parte de Montesquieu: "una previa toma de partido feudal" Sin embargo, este motivo político es recubierto con un motivo teórico, profundamente revolucionario, en el que se descubre su novedad:

Rechazando la teoría del derecho natural y del contrato, Montesquieu rechaza al mismo tiempo las implicaciones filosóficas de su problemática: ante todo, el idealismo. Él se opone por lo menos en su conciencia deliberada, a juzgar el hecho por el derecho, y a proponer so capa de una génesis ideal, un fin a las sociedades humanas. No reconoce más que los hechos. Si no admite que se juzgue lo que es por lo que debe ser, es porque él no extrae sus principios de sus prejuicios, sino de la naturaleza de las cosas.... Prejuicio: ... la idea de que la abstracción de un ideal político, incluso revestido con los principios de la ciencia, puede ocupar el lugar de la historia. En este aspecto, Montesquieu rompía sin miramientos con los teóricos del derecho natural (Althusser, 1974, p. 30).

Es con esas palabras que concluye el capítulo 1 de MPH, reconociendo en la soledad de su tarea -“este hombre está enteramente solo frente a su tarea" (1974, pp. 31)- una novedad filosófica movilizada por un pensamiento políticamente conservador, contra un agotamiento filosófico movilizado por un pensamiento políticamente revolucionario como el de los filósofos del derecho natural.

Llegados hasta aquí se impone pasar en limpio algunas consideraciones. Un estudio a la letra deja a la vista que las referencias a Spinoza, incluso textuales, dan cuenta de un primer ejercicio de lectura del filósofo holandés por parte de Althusser. Pero es evidente que Spinoza emerge como una imagen distorsionada que tiene como propósito mostrar mejor, por contraste, el rostro de Montesquieu. Spinoza, junto a los filósofos del derecho natural, no es más que un espejo deformado que nos devuelve la imagen de Montesquieu como aquel que está solo frente a su tarea. Es evidente también, por lo demás, que estas primeras referencias distan de las tesis que algunos años después defenderá Althusser respecto a Spinoza. Pero no basta con decir que distan, se impone reconocer que la tesis fundamental respecto al lugar que cada figura ocupa en la historia de la filosofía es opuesta: será seis años más tarde que Althusser (2004b) señalará a Spinoza como "el único antepasado directo de Marx" (p. 113).

10 Tiempo después estas, lecturas de los teóricos del derecho natural serán complejizadas por el propio Althusser. Respecto a Hobbes, cf. sus cursos de 1965-1966 y 1971-1972 (Althusser, 2007c, pp. 257-272, 359-384). 
Por otro lado, es evidente que cualquier lector de Spinoza difícilmente acepte reducir su filosofía a un pensamiento que pretende asir la esencia de la sociedad, a un pensamiento ideológico, a un pensamiento que no necesita de la historia para confirmar que el hecho es el resultado de un derecho genético. Pero para revelar que se trata de una mala lectura no es necesario contrastar esta imagen deformada a partir de lo que un spinozismo bien entendido significaría. Basta con contrastarlo con lo que Althusser dijo tiempo después respecto a Spinoza. En un curso sobre filosofía y política en los siglos XVII y XVIII, fundamentalmente dedicado a Rousseau, Althusser (1966-1967/2007b) hizo dos señalamientos capitales sobre Spinoza que lo alejan de su interpretación de 1959. En primer lugar, comentando los conceptos fundamentales de la problemática política del siglo XVII y del siglo XVIII, señala que en figuras como Vico y Montesquieu, por medio de la noción de sociabilidad natural, es posible encontrar otro tipo de argumentación que excluye la problemática del estado de naturaleza y el contrato. Althusser introduce una aclaración - matiz ausente en 1959- respecto a cierto carácter anfibológico del holandés: "(Spinoza piensa en el primer sistema [el del contrato], pero efectivamente está contaminado por esta problemática [la de la sociabilidad natural], y ocupa una posición aparte)" (2007b, p. 253). En segundo lugar, comentando el problema del contrato, Althusser niega que Spinoza recurra a ese dispositivo debido a la imposibilidad filosófica del contrato: "el concepto de contrato postula contratantes iguales, es decir, sujetos jurídicos iguales, cogitos jurídicos (Spinoza rechaza la posibilidad del contrato, porque rechaza la posibilidad teórica del cogito)" (2007b, p. 254).

La imagen deformada de Spinoza que emerge en MPH no solo es notoria, sino que también resulta contraria a lo que posteriormente Althusser afirmará sobre el filósofo holandés. Si bien esta lectura limitada se explica principalmente por el desconocimiento de su filosofía por parte de Althusser, ${ }^{11}$ es necesario correrse de cualquier interpretación idealista que considere un problema de conocimiento como un problema de adecuación de la idea que se tiene al objeto que se estudia. Deben ser estudiadas, en cambio, las causas que producen este efecto de desconocimiento. Es en este registro que quisiera señalar, primero, que esta imagen deformada de Spinoza se debe a una concepción lineal de la historia de la filosofía que todavía impera en esos años en Althusser: de lo que se trata es de trazar el camino a Marx que, por momentos, se nos presenta homogéneo, continuo y acumulativo. En ese camino la historia de la filosofía pareciera funcionar secretamente bajo un supuesto que presupone que la proximidad o lejanía cronológica entre dos autores es razón suficiente para dar con una filiación teórica. En segundo lugar y de manera solidaria con el primer motivo, aquí la referencia filosófica secreta, por fuera de Marx, sigue siendo Hegel, tal como mostraré más adelante.

Pero antes de continuar quisiera destacar una lección. Estas primeras referencias a Spinoza están mediadas por el trabajo, aunque preliminar, sobre el Tractatus politicus y el Tractatus theologico-politicus lo cual sugeriría que el primer acercamiento de Althusser a Spinoza es realizado por medio de la política. Si bien puede llamar la atención la ausencia de referencia a la Ethica, no es sorpresiva esta inclinación hacia las obras políticas. Se trata de un gesto que recorre toda la obra de Althusser: la denuncia a la desconfianza que primaba en la tradición filosófica frente a la política, y el convencimiento de que los filósofos se expresan, o se descubren, en sus pensamientos profundos al momento de enfrentarse a los temas filosóficamente impuros como los que se tornan visibles por medio de la política (cf. Althusser, 2008a, p. 41).

\section{Montesquieu sive Spinoza}

Si bien las menciones a Spinoza se concentran en el capítulo 1 de MPH, hay un conjunto de problemas abordados en los capítulos 2 y 3 que no son ajenos al futuro spinozismo de Althusser. Tanto en el abordaje del problema de la ley-relación, como en el de la dialéctica de la historia puede verse el modo en el que se configuran las condiciones de posibilidad para el inminente ingreso de Althusser en el terreno de la filosofía marxista, pero también de cierto spinozismo.

\section{Una nueva teoría de la ley}

Althusser considera que el rechazo a juzgar lo humano bajo preceptos religiosos, morales o teóricos-abstractos "abre el camino real de la ciencia" y "nos introduce en las grandes revoluciones teóricas de Montesquieu" (1974, p. 33). Para demostrarlo dedica el capítulo 2 a reflexionar sobre la más célebre de estas revoluciones; la que se condensa en De l'esprit des lois, I, I en torno al concepto de ley. Esta concepción de la ley ilustra paradigmáticamente el abandono de una antigua concepción ligada al discurso teológico-político, y su inscripción en "la práctica de las ciencias experimentales modernas" Antes de esta transformación,

\footnotetext{
Este desconocimiento es textual si se considera que las menciones a Spinoza antes de la publicación de MPH son prácticamente inexistentes. Asimismo, si seguimos los documentos conservados en el Fondo Althusser del IMEC podemos confirmar este desconocimiento. En el conjunto de fichas posiblemente preparatorias para la redacción de su Montesquieu (20ALT/60/6, Notes sur Montesquieu), compuestas por un total de 298 páginas, prácticamente no hay referencias a Spinoza y ni a Maquiavelo. En cambio, en las Notes sur Machiavel (20ALT/60/5) y las Notes sur Spinoza (20ALT/60/8) las referencias cruzadas entre Montesquieu, Maquiavelo y Spinoza son muy frecuentes. Todo ocurre como si Althusser leyera de modo sucesivo a Maquiavelo y Spinoza teniendo detrás suyo a quien conocía con anterioridad: Montesquieu.
} 
la ley pertenecía al mundo de la religión, de la moral, de la política... La ley suponía, pues, seres humanos, o seres a la imagen del hombre... La ley era mandamiento. Necesitaba, pues, una voluntad que ordenaba y voluntades que obedecían. Un legislador y súbditos. La ley poseía, por ello, la estructura de la acción humana consciente: tenía un fin, designaba un objeto y al mismo tiempo exigía alcanzarlo (1974, p. 34).

La posibilidad de que las cosas naturales tuvieran leyes concebidas por fuera del esquema de esta herencia se reveló a lo largo de un camino que va de Descartes a Newton. En el medio, Spinoza: el filósofo holandés es nombrado, por última vez en MPH, para señalar que con él "nace la conciencia de una primera diferencia" (1974, p. 35) entre el uso teológico-político de la palabra ley y de su utilización para las cosas naturales. Althusser cita un pasaje del Tractatus theologico-politicus: "la palabra ley parece haber sido aplicada, metafóricamente [per traslationem], a las cosas naturales, ya que habitualmente no se entiende por ley, sino un mandato que los hombres pueden cumplir e igualmente desdeñar" (Spinoza, 1670/2014, IV, p. 167). Pero será con Newton que la ley se desprenderá definitivamente de aquel uso y tomará la forma anunciada por Montesquieu al comienzo de De l'esprit des lois: "las leyes en su más amplia significación son las relaciones necesarias que se derivan de la naturaleza de las cosas" (1748/1984, p. 31). Se trata así de "una relación constantemente establecida" de suerte que "toda diversidad es uniformidad y todo cambio es constancia" (1748/1984, p. 32).

Althusser se declara fiel a esta noción de ley con implicancias ontológicas, epistemológicas y políticas, y la considera constitutiva de una concepción científica que llegará hasta Marx. En esa concepción científica de la ley fue mencionado Spinoza como un pasador en el camino que permitió alcanzarla. Pero si recorremos las implicancias de esta nueva noción de ley, será posible ver que las concepciones de Spinoza y Montesquieu en este tema forman parte de una misma revolución teórica en curso, insuficientemente reconocida por Althusser.

Respecto a las implicancias ontológicas, obsérvese la célebre definición de la ley esgrimida al comienzo De l'esprit des lois, I, I y compáresela con la de Spinoza en el Tractatus theologico-politicus, IV:

Las leyes en su más amplia significación son las relaciones necesarias que se derivan de la naturaleza de las cosas. En este sentido, todos los seres tienen sus leyes: las tiene la divinidad, el mundo material, las inteligencias superiores al hombre, los animales y el hombre mismo (Montesquieu, 1748/1984, I, I, p. 31).

La palabra ley, tomada en sentido absoluto, significa aquello por lo cual los individuos de una misma especie, ya sean todos, ya sean tan solo algunos actúan de una misma forma, fija y determinada [certa ac determinata] (Spinoza, 2014, IV, p.165).

Ambas definiciones comienzan con la pretensión de dar cuenta de las leyes en su acepción más amplia posible ("dans la signification plus étendue", "nomen absolute sumptum"). Ambas, a su modo, plantean la relación entre las cosas ("les êtres", "unumquodque individuum") y Dios ("la divinité", "necessitate naturae"). Ambas, plantean el problema de la relación entre la divinidad y el resto de las cosas. Ambas decretan el fin de las zonas prohibidas para el conocimiento. En este punto, se podría decir que la versión althusseriana de Montesquieu (como Spinoza en la Ética) comienza por Dios para pensar en primer lugar la relación entre las leyes de Dios y el resto de las leyes: "Hay pues una razón primitiva [primitive]. Y las leyes son las relaciones que existen entre esa razón originaria y los distintos seres, así como las relaciones de los diversos seres entre sí" (Montesquieu, 1748/1984, p. 31). Althusser lee en spinozista sin saberse, sin embargo, spinozista (al menos, todo lo spinozista que pueda ser una gramática y una semántica que solo trabajosamente podría adecuarse a la del holandés) esta problemática montesquieviana:

Si se añade que el mismo Dios, que instituye esas leyes al crear los seres, ve que su propio decreto originario queda sometido a una necesidad de idéntica naturaleza, jel propio Dios resulta afectado, desde el interior, por el contagio universal de la ley!... Una vez arregladas las cuentas con Dios, todo lo demás se derrumba. El mejor medio de reducir a un adversario es atraerlo a nuestro partido. Él velaba sobre los antiguos dominios. Y he aquí que se abre ante Montesquieu, y, en primer lugar, el mundo entero de la existencia de los hombres en sus ciudades y en su historia. Por fin va a poder imponerle su ley. (Althusser, 1974, p. 37). ${ }^{12}$

Esto nos lleva a considerar las implicancias epistemológicas de esta teoría de la ley-relación expresadas en De l'esprit des lois, I, III: la distinción entre las leyes positivas de los hombres (de gentes, civiles y políticas) y el espiritu de esas leyes (las leyes de esas leyes). De esta distinción Althusser concluye que Montesquieu no

\footnotetext{
Es de notar la proximidad de este pasaje con las consideraciones que Althusser realizará sobre Spinoza en la década de 1980: "Lo que me fascinaba también en Spinoza era su estrategia filosófica... Toda filosofía es un dispositivo de combate teórico que dispone las tesis como si fueran plazas fuertes o voladizos para poder, en sus alusiones y ataques estratégicos, cercar las plazas teóricas fortificadas y ocupadas por el adversario. ¡Pero Spinoza empezaba por Dios! Empezaba por Dios, y en el fondo (lo creo, como toda la tradición de sus peores enemigos) era ateo.... Suprema estrategia; empezaba por cercar la suprema plaza fuerte de su adversario, o aún mejor, se instalaba en ella como si él mismo fuera su propio adversario y así no sospechoso de ser un adversario declarado, y redisponía esa fortaleza teórica, dándole completamente la vuelta, del mismo modo que se da la vuelta a los cañones dirigiéndolos contra el ocupante" (Althusser, 2007d, p. 138).
} 
confunde "las leyes de su objeto (el espíritu de las leyes) con su objeto mismo (las leyes [positivas])" (1974, p. 39). Se prefigura aquí en filigrana toda una problemática epistemológica que será formulada en spinozista unos años después, en el artículo Sur la dialectique matérialiste (1983e) en la teoría de las tres generalidades (producto de un encuentro virtuoso entre la parte II de la Ethica de Spinoza y la Einleitung a la Crítica de la economía de Marx) y en Lire le capital en la distinción entre objeto real y objeto de conocimiento (2004a).

Más específicamente, Althusser cree que Montesquieu no confunde los resultados de su investigación (el descubrimiento de las leyes de las leyes) con el objeto de investigación científica (las leyes positivas). Es esta diferencia la que permite pensar que el descubrimiento de las leyes (espíritu) que gobiernan las leyes (positivas) no se produce siguiendo un presunto orden natural de esas leyes sino recorriendo el espacio de su diversificación. Fue el propio Montesquieu quien señaló el paso de una física política abstracta a una experimental al reconocer que como el espíritu de las leyes "consiste en las diversas relaciones que las leyes pueden tener con las distintas cosas, he tenido que seguir menos el orden natural de las leyes, que el orden de las relaciones y de las cosas [j'ai dû moins suivre l'ordre naturel des lois, que celui de ces rapports et de ces choses]" (1748/1984, I, III, p. 36). De modo que, para el estudio de las leyes humanas, positivas, puede decirse lo mismo que Georges Canguilhem (2009) dijo del estudio de las leyes biológicas:

[el] medio ambiente que la ciencia define está constituido por leyes, pero tales leyes son abstracciones teóricas. El ser vivo no vive entre leyes sino entre seres y acontecimientos que diversifican esas leyes.... El ser vivo calificado vive entre una multitud de objetos calificados y, por eso mismo, vive entre una multitud de posibles accidentes. Nada existe por azar, pero todo sucede en forma de acontecimientos. He aquí el aspecto por el cual el medio ambiente es infiel. Su infidelidad es en rigor su devenir, su historia. (p. 150).

Esta distinción es importante porque señala el camino para la comprensión de las implicancias políticas presentes en esta concepción de ley, que quisiera describir - con la ayuda de Macherey (2011)- como un esbozo de una teoría inmanente y productiva de las normas. Althusser cree que la distinción entre el objeto de conocimiento y el objeto real, antes que suprimir las diferencias de modalidades expresadas en los objetos reales, es lo que permite asirlas. Más aún cuando tratamos con objetos que parecieran mostrar cierta propensión natural a la errancia. Es lo que hace el propio Montesquieu cuando se traslada de las leyes que rigen la materia inanimada a las que rigen a los animales hasta llegar a los hombres. En esa traslación "a medida que el ser gana en categorías, las leyes pierden su fijeza, y en todo caso su observación pierde exactitud" (Althusser, 1974, p. 39). Montesquieu llega así a una teoría de "los seres particulares inteligentes":

Naturalmente limitados, y por consiguiente, sujetos a error... No solo no siguen constantemente sus leyes originarias, sino que tampoco cumplen siempre las que se dan ellos mismos.... El hombre, en cuanto ser físico, está gobernado por leyes invariables como los demás cuerpos. En cuanto ser inteligente, quebranta sin cesar las leyes fijadas por Dios y cambia las que él mismo establece (1748/1984, I, I, pp. 32-34).

Es justamente este ser errante lo que constituye el objeto de investigación de Montesquieu. ¿Qué decir, se pregunta Althusser, de la relación entre los hombres y sus leyes?:

Que las cambian, las retuercen o las violan. Pero nada de ello afecta a la idea de que puede extraerse de su conducta, indiferentemente sumisa o rebelde, una ley que ellos siguen sin saberlo, deduciendo de sus propios errores su verdad. Para descorazonarse en la tarea de descubrir las leyes de la conducta de los hombres, habría que cometer la simpleza de tomar las leyes que ellos se dan por la necesidad que los gobierna. En verdad, su error, la aberración de su humor, la violación y el cambio de sus leyes, forman parte, simplemente de su conducta. No hay más que extraer las leyes de la violación de las leyes, o de su cambio. Y esto es lo que hace Montesquieu en casi todos los capítulos de Espíritu de las leyes.... el error y la variación humanos constituyen todo su objeto (Althusser, 1974, p. 41).

De una actitud como esta se deriva un reconocimiento constitutivo del materialismo: no confundir los motivos de la acción humana por sus móviles, no juzgar al hombre y sus fines por la consciencia de sí a riesgo de desconocer las causas que lo lleva a obrar. Del mismo modo, no hacer de las leyes que los hombres se dan, la razón de ellas mismas. De ahí se deriva otra lección de materialismo: "Montesquieu no ha pretendido enunciar 'el espíritu' de las leyes, es decir, la ley de las leyes, sin enunciar también el mal espíritu humano de las leyes: la ley de su violación, en un mismo principio" (Althusser, 1974, p. 42). En otros términos: no hay mal espíritu en absoluto, así como no hay lado malo de la historia o no hay sino lado malo de la historia. Nuevamente, puede decirse de lo humano y su historia lo que Canguilhem (2009) decía de la vida:

la vida no es para el ser vivo una deducción monótona, un movimiento rectilíneo, sino que ignora la rigidez geométrica, es debate o ajuste de cuentas... con un medio ambiente en el que hay huidas, agujeros, escamoteos y resistencias inesperadas... No hacemos profesión de indeterminismo.... Sostenemos que la vida de un ser 
vivo, aunque se tratase de una ameba, solo reconoce las categorías de salud y enfermedad en el plano de la experiencia, que es ante todo una prueba en el sentido efectivo del término, y no en el plano de la ciencia. La ciencia explica la experiencia pero no por ello la anula (p. 151).

Se explica así por qué Althusser pareciera encontrar en la concepción de la ley en Montesquieu las claves de una teoría de las normas que rompe con el modelo teológico-político y se acerca a lo que Macherey (2011) señaló como la posibilidad de concebir una historia natural de las normas. Las dos características principales de esta concepción parecieran estar presentes en la lectura que realiza Althusser de Montesquieu: la productividad y la inmanencia de las normas.

En primer lugar, Montesquieu concebiría a las leyes de manera productiva. Desde el momento en que la noción de límite fue cuestionada en su estatuto ontológico, el funcionamiento de las leyes ya no puede pensarse exclusivamente como la imposición de una regla que viene a atravesar y controlar un campo prexistente. Inspirado por Canguilhem, Macherey (2011) habla de una concepción biológica de la norma, destacando justamente su positividad, considerándola

como un movimiento extensivo y creativo que, al ampliar progresivamente los límites de su ámbito de acción, constituye en concreto y por sí mismo el campo de experiencia al que las normas tienen que aplicarse. En este último caso, puede decirse que la norma «produce» los elementos sobre los cuales actúa, al mismo tiempo que elabora los procedimientos y los medios reales de esta acción (p. 91).

En segundo lugar, el carácter inmanente de las normas implica que "ya no se puede pensar la norma misma antes de las consecuencias de su acción, y en cierto modo por detrás y con prescindencia de ellas; por el contrario, hay que pensarla tal y como actúa en sus efectos" (Macherey, 2011, p. 103). Montesquieu, en una expresión que no dejará de tener impacto en Althusser, afirma que "il ne parle pas des causes, et il ne compare point les causes; mais il parle des effets, et il compare les effets [No habla de las causas y no compara las causas; sino que habla de sus efectos, y compara sus efectos]" (Montesquieu, 1750/1979, p. 422). Así, las leyes sólo son posibles de ser pensadas históricamente en relación con los procesos que las ponen en práctica. De ahí que Macherey concluyera su texto señalando el problema de la historicidad al interior de la naturalidad de las normas, dibujando el camino que nos lleva al materialismo histórico como "un nuevo esfuerzo por pensar juntos lo histórico y lo sustancial” (Macherey, 2011, p. 116). Desde este punto de vista, no resulta extraño, entonces, que luego de comentar esta concepción revolucionaria de la ley-relación, Althusser haya pasado a comentar en el capítulo 3 la dialéctica de la historia que esta concepción posibilita.

Así termina de vislumbrarse la implicancia política de este reconocimiento ontológico y epistemológico que permite comprender la distancia existente entre "las leyes que ordenan realmente las acciones de los hombres (las leyes que busca el sabio) y las leyes ordenadas por los hombres" (Althusser, 1974, p. 43). De modo que, en consecuencia, toda la perspicacia del legislador depende del reconocimiento de esa distancia, toda su política depende de su capacidad para "colmar la distancia que separa las leyes que gobiernan a los hombres sin que estos lo sepan, de las leyes que ellos hacen y conocen":

No se trata, pues, de un ideal abstracto, de una tarea infinita que afectaría a los hombres porque éstos son impotentes y nómadas. Se trata de una corrección de la consciencia errante por la consciencia adquirida, de la consciencia inconsciente por la conciencia científica. Se trata pues, de transferir las adquisiciones de la ciencia a la propia práctica, corrigiendo los errores y la inconsciencia de dicha práctica.... Entendido así, Montesquieu es el precursor consciente de toda la ciencia política moderna, que no quiere ciencia, sino crítica, que no separa las leyes reales de la conducta de los hombres de las leyes aparentes que éstos se dan, sino para criticar estas leyes aparentes y modificarlas, devolviendo así a la historia los resultados adquiridos en el conocimiento de la historia (1974, pp. 43-44).

En este desarrollo se entrevé la potencia de un pensamiento sobre los fines de lo político que rehúsa de toda trascendencia. Siendo imposible prescribir normas universales ni fines del hombre, resta reconocer el carácter inmanente de esas normas de modo que todo el problema de la moderación como cualidad del legislador vive de este reconocimiento. Es este mismo desarrollo el que explica por qué Montesquieu se aparta, desde la óptica de Althusser, de un "racionalismo político intransigente y de sus presupuestos teóricos" según el cual sería posible una "reforma del entendimiento en política". Contra una concepción como ésta propia de la Enciclopedia, dice Althusser, Montesquieu se niega a juzgar la ignorancia por una verdad trascendente e ideal. $^{13}$

Llegados hasta aquí es posible reconocer que la concepción de la ley en ruptura con el esquema teológicopolítico que Althusser identifica en Montesquieu no está lejos de la posición que Althusser unos años después

3 En una de sus notas preparatorias Althusser reúne citas De l'esprit des lois que fundamentan esa posición crítica frente al racionalismo político de tipo ilustrado, cf. 20ALT/60/6, Notes sur Montesquieu, "Réforme de l'entendement." 
alcanzará en el ámbito de la filosofía marxista con ayuda de Spinoza. Esto, antes que probar que Spinoza estaba secretamente operando en 1959, señala el modo en el que el encuentro de Althusser con el Spinoza se produce por medio de una sobrecarga de disposiciones previas a través de las cuales Althusser transitaba en la búsqueda de una filosofía que estuviera a la altura de los descubrimientos posibilitados por Marx. Así, el spinozismo de Althusser habría conquistado su posición por condensación, bajo la figura atmosférica de una precipitación.

Más específicamente, el esfuerzo de Althusser por afirmar la posibilidad de teorizar la realidad social sin reducir la pluralidad de determinaciones que alberga en su seno, el rechazo a toda concepción teleológica de la historia y toda filosofía de los orígenes, son elementos que Althusser pareciera encontrar, no sin equívocos, en la posición teórica adoptada por Montesquieu. Estos elementos estarán en la base del trabajo más conocido de Althusser en la década de 1960 en el ámbito de la filosofía marxista. Pero si los temas siguen siendo los mismos, las posiciones teóricas de Althusser se presentarán más elaboradas al ser generalizadas como descubrimientos de Marx; y emergerá, más o menos implícitamente hasta tornarse explícita, otra referencia filosófica que sirva de fundamento. Spinoza será desde entonces la figura teórica que permita desarrollar sin equívocos, o al menos desde una posición tendencialmente materialista, los elementos que Althusser había encontrado en el señor de la Brède. Si esto ocurre así es porque, quisiera sugerir, la lectura de la novedad de Montesquieu continúa teniendo una referencia filosófica fundamental con la que creímos que ya había roto, pero a la que retornará en el capítulo 3 de MPH: Hegel.

\section{La dialéctica de la historia}

Althusser nos dice que la perspectiva de Montesquieu descripta en los capítulos I y II produce algo nuevo. Para dar cuenta de esta producción, nos propone reconsiderar la estructura, la llama disposición, de De l'esprit des lois. Luego del libro I De las leyes en general, del libro II al XIII se enuncia una teoría de los gobiernos, "una tipología que parece muy abstracta"; desde el libro XIV pareciéramos entrar en otro mundo, el de una multiplicidad de variaciones positivas (el clima, la naturaleza del suelo, las costumbres, el comercio, la moneda, el número de habitantes y la religión); finalmente, cerrando la obra, cuatro libros de historia sobre la evolución de las leyes romanas y los orígenes de las leyes feudales. ¿Dónde buscar los principios que reúnan estas tres partes de la obra? ¿hay que buscarlos en el formalismo de una tipología, en el determinismo de una descripción positiva o en una narración del desarrollo histórico de las leyes en Europa?:

Si se quiere abarcar todo en una imposible unidad, la idealidad de los tipos, el determinismo del medio material y moral, y la historia, nos encontramos inmersos en contradicciones sin salida. Se diría que Montesquieu se encuentra desgarrado entre un materialismo mecanicista y un idealismo moral, entre estructuras intemporales y una génesis histórica (Althusser, 1974, p. 53)

Althusser se propone combatir la impresión de una obra desordenada para dar cuenta de la cadena que liga las diferentes verdades de su obra. El eslabón más fuerte de esa cadena se encuentra en la distinción (y simultánea articulación) entre la naturaleza y el principio de un gobierno. Respecto a la naturaleza (De l'esprit des lois, II), Montesquieu nos da una definición elemental; la naturaleza del gobierno se define por cuestiones formales: la detentación y el modo de ejercicio del poder. Con los principios (De l'esprit des lois, III), en cambio, "nos adentramos en la vida", porque un gobierno desde el punto de vista del principio "es la forma de la existencia concreta de una sociedad de hombres" (Althusser, 1974, p. 54). No basta así con el establecimiento de una forma política (república, monarquía, despotismo) sino que "es preciso una disposición de los hombres hacia esa forma, cierta manera de obrar y reaccionar que sostenga esta forma", es preciso, una pasión específica (virtud, honor, miedo [crainte]) que funcione no tanto como un efecto de la naturaleza del gobierno sino más bien como su condición. De ahí que Montesquieu reconociera en el principio el resorte; aquello que hace obrar a un gobierno, su condición de existencia y la vida del gobierno.

Inmediatamente Althusser advierte que, siguiendo este razonamiento, ya no es posible hablar de formalismo en Montesquieu:

solo es concebible, en tanto que real, la totalidad naturaleza-principio. Y esta totalidad ya no es formal, pues no designa una forma jurídica pura, sino una forma política que lleva su propia vida, con sus propias condiciones de existencia y duración.... Como pasión en general, la pasión puede parecer abstracta, pero como principio expresa políticamente toda la vida real de los ciudadanos.... El principio está, pues, en el punto de encuentro de la naturaleza del gobierno (forma jurídica) y de la vida real de los hombres (1974, p. 56).

En este punto, sugiere Althusser, Montesquieu vuelve a apartarse de los teóricos políticos anteriores acercándose a Hegel y Marx en tres puntos. En primer lugar, frente a quienes pretendieron fundar la diversidad de las formas estatales a partir de una lógica de su naturaleza o mediante una descripción de elementos sin unidad interna, Montesquieu descubre al Estado como un principio espiritual unificador: 
[descubre] que el Estado es una totalidad real, y que todos los detalles de su legislación, de sus instituciones, y de sus costumbres no son más que el efecto y la expresión necesarios de su unidad interna. Esas leyes, que parecen fortuitas y sin razón, las somete a una profunda lógica, y las refiere a un centro único (Althusser, 1974, p. 57).

Con Montesquieu, afirma Althusser, la totalidad deja de ser una idea y pasa a ser una hipótesis científica destinada a explicar los hechos. La historia deja de ser un espacio inasible, ahora este espacio "tiene una estructura" con sus respectivos "centros": los Estados. Y al interior de ese centro que es el Estado, se encuentra otro centro; "en el corazón de esas totalidades que son como individuos vivos, hay una razón interna, una unidad interior, un centro originario fundamental: la unidad de la naturaleza y del principio" (1974, p. 58). Fue el mismo Hegel quien rindió homenaje a Montesquieu por este descubrimiento: la relación entre la forma jurídica de un gobierno y la pasión que la mueve permiten explicar el devenir de un Estado en su esplendor, su sobrevida, su caducidad. ${ }^{14}$

A partir de este primer acercamiento de Montesquieu con Hegel, se nos presenta un segundo acercamiento ahora entre Montesquieu y Marx, consistente en haber reflexionado sobre la historia sin pretender asignarle un fin prefijado y en haber propuesto un principio de explicación universal de esa historia:

Montesquieu es sin duda el primero que, antes de Marx, haya emprendido una reflexión sobre la historia sin prestarle un fin, es decir, sin proyectar en el tiempo de la historia la conciencia de los hombres y sus esperanzas... Fue el primero que propuso un principio de explicación universal de la historia, un principio no solamente estático; la totalidad explicando la diversidad de las leyes e instituciones de un gobierno dado; sino dinámico; la ley de la unidad de la naturaleza y del principio, que permitía pensar sobre el devenir de las instituciones y su transformación en la historia real. He aquí el descubrimiento de una relación constante -que une la naturaleza con el principio del gobierno- en la profundidad de esas innumerables leyes pasajeras y mudables; y, en el corazón de esa relación constante, queda enunciada la variación interna de la relación (Althusser, 1974, p. 62).

Es esto lo que permite afirmar que fue Montesquieu quien dio una respuesta al clásico problema del motor de la historia. Pero es importante evitar un equívoco al que nos vemos expuestos consistente en tomar esta reflexión de Montesquieu sobre la relación entre la naturaleza y el principio bajo el esquema de un tipo de "totalidad circular expresiva" en la que cada parte funciona como el todo, como pars totalis, y cuyo movimiento dibuja el círculo de una repetición infinita:

el movimiento de esta esfera, que pensamos movida por una causa, no sería más que su desplazamiento sobre sí misma. Una bola que rueda de abajo arriba, para volver abajo, y así hasta el infinito. Pero todos estos puntos pasan igualmente. No hay arriba ni abajo en una esfera, concentrada enteramente en cada uno de sus puntos (Althusser, 1974, p. 64).

Como puede verse, el argumento se despliega preanunciando toda la crítica a la causalidad expresiva que Althusser desarrollará unos años después en Lire le capital, sin embargo, con una diferencia importante: será Hegel, como es sabido, el señalado como máximo representante de ese tipo de causalidad expresiva. Este giro crítico se encuentra, por lo demás, ausente en MPH. Por el momento, el pensamiento del señor de la Brède se diferencia de ese tipo de causalidad porque en él encontramos un término determinante: "el principio es la verdadera forma de esa forma aparente que es la naturaleza de un gobierno" Althusser traza así una analogía por momentos algo formal pero cargada de efectos:

Por arriesgada que sea esta comparación que enuncio con todas las precauciones, el tipo de determinación en última instancia por el principio, determinación que prevé [ménage], sin embargo, toda una zona de eficacia subordinada a la naturaleza del gobierno, puede parangonarse con el tipo de determinación que Marx atribuye en última instancia a la economía, determinación que prevé [ménage], sin embargo, una zona de eficacia subordinada a la política. En ambos casos, se trata de una unidad que puede ser acorde o contradictoria; en los dos casos existe un elemento determinante en última instancia; y en los dos casos esta determinación deja al elemento determinado toda una región de eficacia, aunque subordinada (Althusser, 1974, pp. 66-67).

Esta relación de determinación en última instancia del principio sobre la naturaleza del gobierno es la que permite reintegrar los libros De l'esprit des lois dedicados a la multiplicidad de determinaciones (el clima, el suelo, el comercio, la religión). El principio que determina en última instancia la naturaleza del gobierno resulta ser la condensación de la diversidad de factores. El principio es "la expresión política del comportamiento

Sobre el homenaje a Montesquieu, a quien Hegel caracterizó como “exacto y profundo." Cf. Hegel, 2004, §3, p. 26, §261, p. 234; Hegel, 2013, p. 398; Hegel, 2010, p. 120. 
concreto de los hombres". A su vez, lo que el principio expresa políticamente es en realidad un complejo de determinaciones indirectas que se reúnen en torno a las nociones de costumbres [mours] y espíritu de un pueblo:

el principio expresa ... la condición de existencia de un gobierno, y remite a la vida real de los hombres como fondo concreto de aquel. Las causalidades paralelas de la segunda parte del Espíritu de las Leyes nos revelan perfectamente los componentes de esta vida real -es decir, las condiciones reales, materiales y morales, de la existencia de ese gobierno-y los resume en las costumbres que afloran en el principio. (Althusser, 1974, p. 74).

Pero es en este territorio conquistado junto a Montesquieu que Althusser ecuentra precisamente el límite del señor de la Brède: la insuficiencia de una concepción que permitiera explicar el pasaje de las costumbres a su expresión política, es decir, a los principios. La consideración de esta insuficiencia es típicamente marxista (será reiterada, por lo demás, respecto a Rousseau hacia 1967 en Sur le Contrat social (2008b): el equívoco de Montesquieu radicaría en su imposibilidad por asir "una unidad más profunda" que los conceptos de principios $y$ de costumbres [mœeurs] (el principio como expresión política de las costumbres, las costumbres como la zona de la multiplicidad de determinaciones propias de la vida real, de las relaciones de los hombres "con la naturaleza y su pasado") no alcanzan a captar. Esa unidad más profunda es la que debería haber sido señalada por "la economía politica" (Althusser, 1974, pp. 75-76). ${ }^{15}$

\section{Montesquieu dentro de sus límites}

Cualquier lector habrá notado que en este tratamiento algo heterodoxo de Montesquieu, y ciertamente movilizado por fines propios, Althusser desarrolla preliminarmente los trazos de lo que será uno de sus desarrollos filosóficos más importantes en torno al problema de la causalidad tal como éste se expresará en Contradiction et surdétermination: el simultáneo reconocimiento de la determinación en última instancia por la economía y de la zona de eficacia propia de la política. Es evidente también que en este desarrollo pareciera jugar un concepto ausente todavía, aunque presente en sus efectos: el de sobredeterminación. Lo sorprendente es, sin embargo, que la referencia teórica que posibilita esta formulación es un linaje Montesquieu-Hegel-Marx, confirmando el desconocimiento de Althusser respecto a las posibilidades que brindaba una filosofía como la de Spinoza frente al pensamiento hegeliano. Es así como, pocos años después, Althusser (1983d) afirmará que la formulación del concepto de sobredeterminación para describir la recursividad de una situación "determinante pero también determinada en un solo y mismo movimiento" depende de la posibilidad de deshacernos de la dialéctica hegeliana puesto que ella no está nunca realmente sobredeterminada:

Círculo de círculos, la conciencia [en Hegel] no tiene sino un centro, que es el único que la determina necesitaría poseer círculos que tuvieran otro centro que el de ella, círculos descentrados para que pudiera ser afectada en su centro por su eficacia, para que su esencia fuera sobredeterminada por ellos (1983d, p. 82).

En estas páginas de Pour Marx el linaje alcanzado en MPH es cuestionado de manera fundamental al punto de que la originalidad de Marx solo será reconocible ya no con, sino contra Hegel (y Montesquieu) como condensación de un tipo de totalidad expresiva en la que sus partes no hacen más que expresar la totalidad social de la que participan puesto que cada una contiene de manera inmediata la esencia de dicha totalidad. Analizando la noción hegeliana de la contradicción, en lo que se trata por lo demás de la única mención a Montesquieu en Pour Marx, Althusser sintetizó:

Basta entonces interrogarse sobre la razón por la que los fenómenos de la mutación histórica son pensados por Hegel en este concepto simple de la contradicción, para plantear justamente la cuestión esencial. La simplicidad de la contradicción hegeliana no es posible, en efecto, sino a partir de la simplicidad del principio interno que constituye la esencia de todo período histórico. Es debido a que es posible de derecho reducir la totalidad y la infinita diversidad de una sociedad histórica dada (Grecia, Roma, el Sacro Imperio, Inglaterra, etc....) a un principio interno simple, que esta misma simplicidad, adquirida así de derecho a la contradicción, puede reflejarse en ella.... Esta reducción misma (cuya idea sacó Hegel de Montesquieu), la reducción de todos los elementos que forman la vida concreta de un mundo histórico (instituciones económicas, sociales, políticas, jurídicas, costumbres, moral, arte, religión, filosofía, y hasta los acontecimientos históricos: guerras, batallas, derrotas, etc.) a un principio de unidad interna, esta reducción misma no es en sí posible sino bajo la condición absoluta de considerar toda la vida concreta de un pueblo como la exteriorización-enajenación (Entäusserung-Entfremdung) de un principio espiritual interno que no es, en definitiva, sino la forma abstracta

Sobre los límites de este giro argumentativo en Althusser ver Spector (2017). 
de la conciencia de sí de ese mundo: su conciencia religiosa o filosófica, es decir, su propia ideología (1983d, pp. 83-84).

El acercamiento entre Hegel y Montesquieu (y su diferencia frente a Marx) es lo que explica que por aquella misma época en el seminario sobre los orígenes del estructuralismo Althusser se haya remontado hasta Montesquieu para trazar, según el título anunciado, una prehistoria del estructuralismo de Montesquieu a Dilthey. Siguiendo estos documentos es posible reconocer que Montesquieu aparece limitado frente a la imagen de él construida en hacia 1959 en MPH. Mientras que los intentos por diferenciar su perspectiva de toda pretensión formalista ya no se hacen visibles, de ahora en adelante está listo para que sus categorías y problemas (la noción de ley-relación, la unidad naturaleza-principio como dialéctica de la historia) sean inscriptas en una problemática estructuralista. Una problemática de la que Althusser vive pero que simultáneamente intenta, si no demarcarse de manera definitiva, sí al menos trazar la pendiente que señale una diversificación en su despliegue respecto a -como dirá más tarde, retrospectivamente- "su tendencia general: racionalista, mecanicista, pero por encima de todo formalista" según la cual "tiende hacia el ideal de la producción de lo real bajo el efecto de una combinatoria de elementos indistintos" (Althusser, 2008c, p. 191). Frente a esa tendencia se trata de pensar la especificidad de una combinación que no se reduzca a la combinatoria formal de elementos equivalentes que hace de cada uno de estos elementos pars totalis que expresión de la totalidad social en su inmediatez.

Llegado hasta aquí es posible reconocer la importancia del estudio de MPH para la comprensión de la evolución teórica de Althusser. Todo indica que Montesquieu fue esa figura filosófica que le permitió vivir la paradoja de un pensamiento que empieza a nacer. Análogamente a Marx frente a Feuerbach, pareciera que Althusser con Montesquieu "se ve sometido a la condición paradójica de tener que aprender el arte que le permitirá decir lo que va a descubrir en aquello mismo que debe olvidar" (Althusser, 1983c, p. 70). Es esto mismo lo que le da su texto el carácter de una permanencia y de una inminencia, como Althusser mismo dijera respecto a los escritos del joven Marx. De este modo, lo afirmado por Althusser respecto a la originalidad de Montesquieu no se pierde sino que se expresa en sus efectos en trazos significativos de su futura obra. Como ha concluido Panagiotis Sotiris (2020), el encuentro de Althusser con Montesquieu no debe ser pensado sólo como una preparación teórica antes del impulso de su obra principal en el ámbito de la filosofía marxista, sino como un "primer intento por lidiar con algunas preguntas que continuarán preocupándolo hasta el final de su vida" (p. 48).

Ya sea en el rechazo a las filosofías del origen, ya sea en el descubrimiento de las implicancias ontológicas, epistemológicas y políticas de una nueva concepción de la noción de ley, ya sea finalmente en la indagación sobre los procesos de causalidad histórica atravesados por múltiples determinaciones, Althusser encuentra en Montesquieu un punto de apoyo provisorio a través del cual pensar estas cuestiones. Ocurre que Althusser tardó en reconocer que aquello que se presentaba como un paso adelante en la historia de la filosofía (según una concepción lineal y evolutiva tributaria de Hegel) encontraría sus límites si no continuaba avanzando. Descubrirá así que el pensamiento de Marx es incomprensible en el marco de esta progresión histórica y que es necesario retroceder un paso para luego dar dos al frente. Eso es lo que posibilitará la lectura de Spinoza. Una lectura que, motivada por la necesidad de "fundar sobre un nuevo elemento su pensamiento teórico" (Althusser, 1983b, p. 37), súbitamente ocupará su lugar.

\section{Referencias bibliográficas}

Althusser, Louis (s.f). Notes sur Machiavel [Notas sobre Maquiavelo]. En Fondo Althusser, 20ALT/60/5. IMEC.

Althusser, Louis (s.f). Notes sur Spinoza [Notas sobre Spinoza]. En Fondo Althusser, 20ALT/60/8. IMEC.

Althusser, Louis (ca. 1958-1959). Notes sur Montesquieu [Notas sobre Montesquieu]. En Fondo Althusser, 20ALT/60/6. IMEC.

Althusser, Louis (ca. 1962-1963). Séminaire 1962-1963 [Seminario 1962-1963]. En Fondo Althusser, 813ALT/40/1-6. IMEC.

Althusser, Louis (1974). Montesquieu. La política y la historia. (María Ester Benítez, Trad.). Ariel.

Althusser, Louis (1982). Positions [Posiciones]. Éditions sociales.

Althusser, Louis (1983a). La revolución teórica de Marx (Marta Harnecker, Trad.). Siglo XXI.

Althusser, Louis (1983b). Los 'Manifiestos filosóficos' de Feuerbach. En L. Althusser, La revolución teórica de Marx (Marta Harnecker, Trad., pp. 33-38). Siglo XXI.

Althusser, Louis (1983c). Sobre el joven Marx. (Cuestiones de teoría). En L. Althusser, La revolución teórica de Marx (Marta Harnecker, Trad., pp. 39-70). Siglo XXI.

Althusser, Louis (1983d). Contradicción y sobredeterminación. (Notas para una investigación). En L. Althusser, La revolución teórica de Marx (Marta Harnecker, Trad., pp. 71-106). Siglo XXI.

Althusser, Louis (1983e). Sobre la dialéctica materialista (de la desigualdad de los orígenes). En L. Althusser, La revolución teórica de Marx (Marta Harnecker, Trad., pp. 132-181). Siglo XXI. 
Althusser, Louis (1994). Du contenu dans la pensée de G. W. F. Hegel [Del contenido en el pensamiento de G. W. F. Hegel]. En L. Althusser, Écrits philosophiques et politiques t. 1 (pp. 59-238). STOCK/IMEC.

Althusser, Louis (2004a). De El capital a la filosofía de Marx. En L. Althusser y É. Balibar, Para leer El capital (Marta Harnecker, Trad., pp. 18-77). Siglo XXI.

Althusser, Louis (2004b). El objeto de El capital. En L. Althusser y É. Balibar, Para leer el capital (Marta Harnecker, Trad., pp. 81-215). Siglo XXI.

Althusser, Louis (2007a). Los problemas de la filosofía de la historia (1955-1956). En L. Althusser, Política e historia. De Maquiavelo a Marx (Sandra Garzonio, Trad., pp. 23-185). Katz. DOI: https://doi.org/10.2307/j.ctvm7bd8g

Althusser, Louis (2007b). Rousseau y sus predecesores. La filosofía política en el siglo XVII y en el siglo XVIII (19651966). En L. Althusser, Política e historia. De Maquiavelo a Marx (Sandra Garzonio, Trad., pp. 247-358). Katz. DOI: https://doi.org/10.2307/j.ctvm7bd8g

Althusser, Louis (2007c). Hobbes (1971-1972). En L. Althusser, Política e historia. De Maquiavelo a Marx (Sandra Garzonio, Trad., pp. 359-384). Katz. DOI: https://doi.org/10.2307/j.ctvm7bd8g

Althusser, Louis (2007d). La única tradición materialista. (Juan Pedro García del Campo, Trad.) Youkali: revista crítica de las artes y el pensamiento, 4, 140-154.

Althusser, Louis (2008a). Recensión del libro de Raymond Polin, La politique morale de John Locke. En L. Althusser, La soledad de Maquiavelo (Raúl Sánchez Cedillo, Trad., pp. 35-45). Akal.

Althusser, Louis (2008b). Sobre el 'Contrato social'. En L. Althusser, La soledad de Maquiavelo (Carlos Prieto del Campo, Trad., pp. 63-109). Akal.

Althusser, Louis (2008c). Elementos de autocrítica. En L. Althusser, La soledad de Maquiavelo (Carlos Prieto del Campo, Trad., pp. 169-208). Akal.

Barthes, Roland (1990). La cámara lúcida. Nota sobre la fotografía (Joaquim Sala-Sanahuja, Trad.). Paidós.

Canguilhem, Georges (2009). Lo normal y lo patológico (Ricardo Potschart, Trad.) Siglo XXI.

Durkheim, Émile (2001). Montesquieu y Rousseau. Precursores de la sociología (Rubén Sierra Mejía, Trad.). Miño y Dávila. (Trabajo original publicado en 1892)

Hegel, Georg W. F. (2004). Principios de la filosofía del derecho (Juan Luis Vermal, Trad.). Sudamericana. (Trabajo original publicado en 1833)

Hegel, Georg W. F. (2010). Filosofia de la historia universal (José Gaos, Trad.). Losada. (Trabajo original publicado en 1837).

Hegel, Georg W. F. (2013). Lecciones sobre la historia de la filosofía III (Wenceslao Roces, Trad.). Fondo de Cultura Económica. (Trabajo original publicado en 1833).

Israel, Jonathan I. (2017). La ilustración radical. La filosofía y la construcción de la modernidad, 1650-1750 (Ana Tamarit, Trad.). Fondo de Cultura Económica.

Macherey, Pierre (2011). De Canguilhem a Foucault: la fuerza de las normas (Horacio Pons, Trad.) Buenos Aires: Amorrortu.

Montag, Warren (2013). Althusser and his contemporaries. Philosophy's perpetual war [Althusser y sus contemporáneos. La guerra perpetua de la filosofía]. Duke University. DOI: https://doi.org/10.1215/9780822399049

Montesquieu (1979). Défense de l'esprit des lois [Defensa del espíritu de las leyes]. En Montesquieu, De l'Esprit des lois (Vols. 1-2, pp. 417-469). Garnier-Flammarion. (Trabajo original publicado en 1750).

Montesquieu (1984). Del espíritu de las leyes (Mercedez Blázquez y Pedro de Vega, Trads.). Orbis. (Trabajo original publicado en 1748).

Montesquieu (2000). Cartas persas (José Marchena, Trad.). Alianza. (Trabajo original publicado en 1721).

Peden, Knox (2014). Spinoza contra phenomenology. French rationalism from Cavaillès to Deleuze [Spinoza contra fenomenología. El racionalismo francés de Cavaillès a Deleuze]. Standford University.

Sánchez Estop, Juan Domingo (2020). Spinoza dans Althusser. Présence et effets du spinozisme dans l'œuvre de Louis Althusser [Spinoza en Althusser. Presencia y efectos del spinozismo en la obra de Louis Althusser]. Tesis doctoral, Université Libre de Bruxelles, Faculté de Philosophie et Sciences sociales, Bruselas. Recuperado de: http://hdl.handle. net/2013/ULB-DIPOT:oai:dipot.ulb.ac.be:2013/301962

Sotiris, Panagiotis (2020). A Philosophy for Communism. Rethinking Althusser [Una filosofía para el comunismo. Repensando a Althusser]. Brill. DOI: https://doi.org/10.1163/9789004291362_014

Spector, Céline (2016) Montesquieu. Libertad, derecho e historia (Victor Goldstein, Trad.). Jusbaires.

Spector, Céline (2017). L'équivoque du concept de mœurs. La lecture althussérienne de Montesquieu [El equívoco del concepto de costumbres. La lectura althusseriana de Montesquieu]. En F. Toto, L. Simonetta, y G. Bottini, Entre nature et histoire. Mours et coutumes dans la philosophie moderne (pp. 191-203). Classiques Garnier. DOI: http:// dx.doi.org/10.15122/isbn.978-2-406-07164-8.p.0191

Spinoza, Baruch (2010). Tratado Político (Atilano Dominguez, Trad.). Alianza. (Trabajo original publicado en 1677).

Spinoza, Baruch (2014). Tratado teológico-político (Atilano Dominguez, Trad.). Alianza. (Trabajo original publicado en 1670).

Vernière, Paul (1954). Spinoza et la pensé française avant la révolution. Deuxième partie, le XVIIIe siècle [Spinoza y el pensamiento francés antes de la revolución. Segunda parte, el siglo XVIII]. Presses Universitaires de France. 